\title{
Multilingual young people as writers in a global age
}

\author{
Joke Dewilde
}

\section{Introduction}

This chapter is about sixteen-year-old Bahar (pseudonym) who grew up in Afghanistan and moved with her family to Norway at the beginning of her teens. Bahar is transnational in the sense that she has "moved bodily across national borders while maintaining and cultivating practices tied-in varying degrees-to [her] home countr[y]" (Hornberger, 2007: 325). She draws on a range of languages on a daily basis, including, but not limited to, Dari, Norwegian and English. When Bahar gave me access to her Facebook profile, I wrote the following fieldnote:

Bahar has given me access to her Facebook profile. As I scroll down, I am reminded of her complex cultural and linguistic background. I see video clips from Afghan artists, pictures from her favourite football team FC Barcelona saying "VISCA EL BARCAAAA", messages where she congratulates Norway on its national day, a picture with the words "I am Farkhunda. Justice for Afghan women." I see communication drawing on Dari with the Latin and Persian alphabets, on Norwegian, English and Catalan. I see emoticons like smileys with eyes in the shape of hearts, lips, hands that clap and flowers. (Fieldnote, 12.5.2014)

This fieldnote illustrates the complex world many young people navigate in terms of linguistic and cultural diversity. Bahar's diverse communicative practices on Facebook were not a surprise to me, but rather an extension of the practices I observed earlier in my fieldwork in the upper secondary school she and her friends attend, where during lunch breaks they animatedly drew on their communicative repertoires. This chapter focuses on how Bahar skilfully extends these social practices in two of her school writings, more specifically in two texts for the subjects Norwegian and English, respectively. The aim is to investigate the social space she creates in her school writings by drawing on the full range of her communicative repertoire.

Unlike Facebook and school breaks, Norwegian classrooms appear very much as 'Norwegian only' zones, especially when it comes to teaching and learning (Dewilde, 2013; Hvistendahl, 2009). This is in line with both general policies and educational language policies which stress the importance of the Norwegian language as a common language for the nation (MER, 2007; MCC, 2007). More recent minority languages (and their users) should be respected, but it is up to the users themselves to further develop their language competence. In a similar vein, the current national curriculum has been criticised for leading to cultural homogenising practices, though in a more covert way than the previous curriculum. The imagined community continues to be built on the vision of one language, one culture and one nation, while other identities are actively dismantled (Engen, 2010, 2014; Vedøy, 2008). However, this does not mean that pupils passively relate to homogenising powers in 
Dewilde, J. (2017). Multilingual young people as writers in a global age. I B. Paulsrud, J. Rosén, B. Straszer \& A. Wedin (Red.), New perspectives on translanguaging and education (s. 56-71). Clevedon: Multilingual Matters.

See: http://www.multilingual-matters.com/display.asp?isb=9781783097807

classrooms. Creese and Blackledge (2010), for example, found that behind their teachers' backs young people tapped into the rich communicative ecologies found in complementary school classrooms in the UK.

Bahar's multilingual writing on Facebook is not a new phenomenon. Defining multilingual literacy as "any and all instances in which communication occurs in two (or more languages) in or around writing" (Hornberger, 1990: 213), it is an ancient phenomenon which can be traced back to Roman antiquity, involving several other languages and Greek in contact with Latin (Adams, 2003). Hornberger's (2003) 'continua of biliteracy' is well-known for bringing together the fields of bi/multilingualism and literacy. It provides a framework for understanding biliteracy in a multifaceted manner as it demonstrates the importance of context, media, and content for the development of an individual's biliteracy.

In a vast body of research on multilingual literacy, studies from across the world have contributed to more nuanced understandings of non-linear literacy development and a more complex understanding of "the relationship between transnational processes, social practices, and the social identities of multilingual learners themselves" (Warriner, 2012: 508). Of particular interest for this chapter is recent work that has explored how literacy practices, identity construction and educational opportunities are affected by the movement of people, ideas, goods and practices. These studies apply a transnational understanding of literacy and have investigated immigrant pupils' literacy practices across home, school and community contexts, and illuminated how these influence learning, identity (trans)formation and larger historical processes (Warriner, 2007: 213).

Multilingualism is a natural part of most transnational people's lives. This is certainly also the case for Bahar. To analyse her writings, Li Wei's concept (2011) of translanguaging space, which embraces creativity and criticality, is presented in the next section. Following this, my own study is introducted, focusing on Bahar as a writer in the remainder of the chapter.

\section{Translanguaging space}

The concept of translanguaging is here taken to mean "multiple discursive practices in which bilinguals engage in order to make sense of their bilingual worlds" (García, 2009: 51; italics in original). At the core of this understanding is the assumption that multilinguals' 'languages' posit a single repertoire from which they strategically select, rather than two or more separate languages that they shift between (see also Creese \& Blackledge, 2010). Accordingly, the act of translanguaging is transformative in nature:

it creates a social space for the multilingual language user by bringing together different dimensions of their personal history, experience and environment, their attitude, belief and ideology, their cognitive and physical capacity into one coordinated and meaningful performance, and making it into a lived experience. (Li Wei, 2011: 1223) 
Dewilde, J. (2017). Multilingual young people as writers in a global age. I B. Paulsrud, J. Rosén, B. Straszer \& A. Wedin (Red.), New perspectives on translanguaging and education (s. 56-71). Clevedon: Multilingual Matters.

See: http://www.multilingual-matters.com/display.asp?isb=9781783097807

Li Wei (2011: 1223) calls the act of translanguaging and the social space it creates for multilingual language users a translanguaging space. This is not a space where separate identities, values and practices co-exist, but rather a space where cultural translation (cf.

Bhabha, 1994) between traditions takes place, as they combine into new identities, values and practices.

The boundaries of the imagined translanguaging space are ever shifting. The individual creates the rules of interaction and interpretation within the space in line with the perceived boundaries. Also, the space constructed by the individual is always located in a wider social space and links to the spaces created by others. The individual's personal histories and experiences, attitudes and values have been acquired in interaction with others under certain social-historical conditions. Finally, a translanguaging space is a lived space, created through social practices in everyday life (Li Wei, 2011: 1223).

The idea of a translanguaging space embraces both creativity and criticality: creativity in the sense that language users have the ability to choose between following or disdaining language norms, and criticality in that existing views are questioned, problematized and expressed. These two concepts are intrinsically linked; that is, it is not possible to be creative without being critical, and vice versa. Today's global world and increased contact between people from diverse linguistic and cultural backgrounds provide new opportunities for innovation (Li Wei, 2011: 1223-1224).

The dynamic and transformative understandings of 'language' and 'culture' at the core of translanguaging acts and translanguaging space harmonise well with the view of language underlying the notion of transnational literacy practices. On a general level, transnationalism challenges the understanding of separate nations and national identity. Rather it is concerned with "the condition of cultural interconnectedness and mobility across space" (Ong, 1999), and it draws attention to how transnational people sustain and further develop social relations with earlier countries of residence and make links between these and their new country. Transnational literacies refer to "literacy practices whose referents and meanings extend across national borders" (Warriner, 2007: 201). In this sense, creative and critical practices are expressions concerned with writers' abilities to push and break boundaries by drawing on situated literacy experiences and established world views that are transferred to and transformed in a new setting where other conventions and expectations are foregrounded.

Dewilde and Igland (2015) apply this notion of multilingual (and transnational) literacy practices to extend the understanding of translanguaging acts. When a multilingual pupil adheres to a particular language in a specific school situation, this is not a translanguaging act in the sense of hybrid language practices. However, it may still rely heavily on multilingual and transnational communicative practices that are part of the pupil's repertoire. Dewilde and Igland illustrate their point by drawing on the writing practices of Mohammed, a Muslim young person, who is found to connect and transform literacy practices that are well established in his 'culture' and in school settings he has experienced before. Accordingly, his writing in Norwegian may also be understood and characterised as a translanguaging act within a translanguaging space. This understanding will be further illustrated below. My understanding of translanguaging in literacy relates to Baker's (2003: 82) notion of 
Dewilde, J. (2017). Multilingual young people as writers in a global age. I B. Paulsrud, J. Rosén, B. Straszer \& A. Wedin (Red.), New perspectives on translanguaging and education (s. 56-71). Clevedon: Multilingual Matters.

See: http://www.multilingual-matters.com/display.asp?isb=9781783097807

'transliteracy', which derives from William's understanding of 'translanguaging' and describes a practice where the input of literacy is in one language and the output in another. In this chapter, however, my main concern is not the fact that a language is strategically used in a given context, but rather that pupils' seemingly monolingual writings include traces from their broader transnational repertoires, and how these traces contribute to the creation of a translingual space.

\section{Zooming in on Bahar's writings}

Bahar is a participant in a year-long linguistic ethnography conducted as part of a larger Nordic research project on successful newcomers and school communities called Learning Spaces for Inclusion and Social Justice. Success Stories of Immigrant Students and School Communities in Four Nordic Countries, financed by NordForsk, 2013-2015. At the time of the study, she was in her first year of the Programme for Specialization in General Studies in a large upper secondary school in the East of Norway. In addition to Bahar, five more pupils participated in the study. They had backgrounds from Afghanistan, Eritrea, Iraq and Somalia, had lived in Norway for approximately five years. The pupils had been identified by their teachers as being particularly successful in and outside of school, given the fact that they were all late arrivals to Norwegian school.

The data for the project have been produced by means of linguistic ethnographical methods (Copland \& Creese, 2015: 30-57), which in this case comprise participant observation in and outside of school, audio recorded field conversations and naturally occurring interaction and semi-structured interviews. In addition, the pupils were actively involved in the research project and were asked to suggest ways which would allow me to get to know them (Dewilde, in press). Bahar suggested that I study her through her writings. More precisely, she gave me access to the two texts analysed here, as well as to her Facebook profile. By agreement with Bahar, Facebook texts from September 2012 up to June 2015 are part of the data. When I wished to include Bahar's friends' interaction in publications, they were asked by Bahar to give their consent.

Bahar's texts were scrutinised by close reading, focusing on significant details (e.g. poetry) and larger patterns (e.g. construction of society). Consistent with linguistic ethnographic analyses, these details and patterns were seen in the light of larger patterns in the fieldnotes and transcripts. During the process of textual analysis, I had frequent contact with Bahar who explained and elaborated on issues that I identified.

\section{"The last thing you will see is a face of love"}


Dewilde, J. (2017). Multilingual young people as writers in a global age. I B. Paulsrud, J. Rosén, B. Straszer \& A. Wedin (Red.), New perspectives on translanguaging and education (s. 56-71). Clevedon: Multilingual Matters.

See: http://www.multilingual-matters.com/display.asp?isb=9781783097807

In this section, the first text Bahar selected for me is presented. It was written in connection with an assignment for the subject Norwegian, where the teacher allowed the pupils to form small groups. Bahar chose to work together with Hasna and Petras (all pseudonyms). Hasna was born in Iraq and came to Norway five years before the research project began, having spent two years in transit in Turkey, Greece, Germany and Sweden. Petras was born in Lithuania and moved to Norway with his family four years before the project started. Hasna speaks Arabic at home, and Petras Lithuanian.

The school assignment was to write a manuscript for an audio play in small groups and then record it. The manuscript was to be a text in a genre of their own choice, such as a drama with dialogue, a story, a short story, a poem, an essay, an item on the news, or a radio show. The pupils were told that creativity and originality were important. The manuscript was to be at least a page long and was to be based on one of several documents, which consisted of extracts from two poems by the Norwegian poets Heikki Gröhn and Maria Parr, respectively, and a photograph of a soccer ball in front of a goal on a soccer field, a copy of Sjøtrollet (The sea troll) a painting by the Norwegian painter Theodor Kittelsen (1857-1914), and of photo of the back of a woman in a white dress who is looking towards a tornado. The origin of the latter picture is unknown to me. Bahar and her peers chose the tornado picture and used it as inspiration for a love story between the main characters Gabrielle and Fernando. Whereas Bahar and Hasna contributed equally much in the writing process, Petras quickly went on to work on an assignment in another subject with an approaching deadline. The text is 493 words long. Apart from the first paragraph, which sets the scene, and the second to last paragraph, which describes the tragic turning point, it consists of dialogue between Gabrielle and Fernando, ten exchanges in total.

The story goes as follows: Fernando has been travelling for four years, when he returns to the village where Gabrielle has been waiting for him. She sits at the foot of the hill thinking of her love and yearning to be reunited with him, when she suddenly hears Fernando calling her name. Her heart starts to pound, and she feels how it fills with joy. Fernando and Gabrielle run towards each other, declare their love, and decide to get married. When the wedding day arrives, Gabrielle puts on her white dress and Fernando his black suit. Unfortunately, the weather changes, and a hurricane takes Fernando and many other people. Gabrielle is left behind in despair. The story ends by Gabrielle calling out that she does not want to live without Fernando, who promised never to leave her behind.

The investigation of how the young writers construct the setting of their love story gives an indication of how they perceive societies and the power relations within them. The pupils choose to situate the action in a village somewhere in Latin America. This is how they start their story: (The language or layout of the excerpts have not been changed. The translations are mine.)

\section{Extract 1.}

Det er ein varm sommerdag, sola skinner over hele landsbyen og traerne danser, mens vinden blåser $i$ Latin America. [It is a warm summer day, the sun is shining 
Dewilde, J. (2017). Multilingual young people as writers in a global age. I B. Paulsrud, J. Rosén, B. Straszer \& A. Wedin (Red.), New perspectives on translanguaging and education (s. 56-71). Clevedon: Multilingual Matters.

See: http://www.multilingual-matters.com/display.asp?isb=9781783097807

\section{over the entire village and the trees are dancing, while the wind blows in Latin} America.]

As we see, the extract contains references to geography, that is, 'landsbyen' (the village) and to nature elements, that is, warmth, sun, wind and trees. The choice of the Norwegian word 'landsbyen' reinforces that the setting is a village abroad. We learn that there are trees that dance, and later in the text there is reference to 'fjell bakken' (the mountain hill/slope/ground) and 'området' (the area). '[F]jell bakken' is not a compound word in Norwegian. 'Fjell' means hill. In the illustration, a woman stands at the foot of the hill, which could indicate that the pupils look for a way to describe this and choose the word 'bakken', in the sense of 'the ground'. The reference to 'the area' does not reveal the complexity which is later played out. As we will see, this complexity is largely due to the characters' outer and inner mobility. In other words, the pupils' construct a village which, at least on the surface, appears peaceful and homogeneous, perhaps mirroring the Norwegian society they are part of (cf. Li Wei, 2011).

In terms of natural elements, the warm weather, the sun, and the (presumably warm) winds that blow, all build up a positive atmosphere in the place. In the next line, the blue sky is also mentioned, further emphasising the good weather. Towards the end, however, when the weather changes, the sun suddenly disappears, the winds take over, the hurricane comes, and there is 'smog'. Just before the weather changes, Gabrielle wants to announce their engagement to the whole village. However, the wedding never takes places as the hurricane takes Fernando away. We do not know where Fernando has been during the past; he may have been abroad or in another place inside the country. We are left to wonder if the characters' mobility stands in contrast to more uniform powers in the village which do not welcome intercultural marriages, or marriages between people with different life biographies. The pupils' linking of the story's weather with powerful societal forces is both a creative and critical act as it questions and challenges homogenising cultural norms and conventions.

The way in which Bahar, Hasna and Petras construct the characters in the story gives an insight into the way they perceive different people's possibilities for manoeuvre within society. This construction comes mainly to the fore through the dialogue between the main characters Fernando and Gabrielle, that is, through poetry and multilingualism. When Fernando and Gabrielle meet, they fall in each other's arms and declare their love by declaiming poetic verses:

\section{Extract 2.}

Fernando: I dine $\varnothing$ yne [In your eyes]

er jeg fortapt [I am lost]

Fortapt av all ømheten [Lost by all tendernes]

som stråler ut [which shines]

legger seg rundt meg [lies itself around me]

$[\ldots]$

Gabrielle: Slår [Beats]

Og slår [And beats] 
Dewilde, J. (2017). Multilingual young people as writers in a global age. I B. Paulsrud, J. Rosén, B. Straszer \& A. Wedin (Red.), New perspectives on translanguaging and education (s. 56-71). Clevedon: Multilingual Matters.

See: $\underline{\text { http://www.multilingual-matters.com/display.asp?isb=9781783097807 }}$

50-70 slag pr minutt [50-70 strikes pr minute]

Blфder og blфder, gjennom sorgen. [Bleed and bleed, through my sorrow.]

Kroppen stopper, når du stopper. [My body stops, when you stop.]

It is not common in contemporary Norwegian/Western literature (for children and young people) to have dialogue between characters in the form of poetic verses. When I asked Bahar about her inspiration, she replied as follows:

\section{Extract 3.}

Slike historier og dikt er ganske vanlige i afghanske og persiske romaner. Jeg husker dem godt. Bestefar pleide å fortelle meg sånne historier, og jeg har lest dem på skole også. Hvis jeg trengte hjelp med skolearbeid så hjalp han meg, mesteparten var alltid å oversette og forklare dikt og fortellinger på enklere måte. Jeg elsket å få hans hjelp. Også pleide han å lage dikt for meg og sang den høyt. [Stories and poems like that are fairly common in Afghan and Persian novels. I remember them well. My granddad used to tell stories like that and I read them in school as well. When I needed help with my homework then he helped me, mostly it was translating and explaining poems and stories in simpler ways. I loved getting his help. And he also wrote poems to me and sang it aloud.]

Bahar is socialised into a literary culture where poetry is central, not only as single poems, but also poems as part of stories. In the assignment, she suggested the inclusion of poetry to Hasna. We thus see how Bahar draws on earlier experiences and transfers them to a different context and a different language. Moreover, the link back in time and place to her grandfather illustrates "an intense social experience and emotional investment," characteristic for a translanguaging space (Li Wei, 2011: 1224). Dewilde and Igland (2015) have previously written about another pupil in the study, Mohammed, who wrote short diary-like texts in Norwegian in his spare time inspired by verses of the Quran which he listened to in Arabic from an app on his mobile phone. Even though these young people are not found to mix different languages here, their language practices are still translanguaging acts since their texts are clearly influenced by their complex linguistic (and in Mohammed's case also religious) backgrounds. Indeed, the young people contribute to genres travelling across time and space, ultimately creating something new, and thus challenging Western genres as we know them.

The other way Bahar, Hasna and Petras construct their characters is by drawing on multiple languages, not unlike Bahar's communication on Facebook or during school breaks (cf. introductory fieldnote). The entire text is written Norwegian. Interestingly, however, Fernando declares his love to Gabrielle in seven different languages/language varieties. The lines are numbered for the purpose of analysis.

\section{Extract 4.}

1 Fernando: «den dagen kom, den dagen vi har ventet på lenge, den dagen blir du min for allid» [«this day came, this day we have been waiting for so long, this day you will be mine for ever»] 
Dewilde, J. (2017). Multilingual young people as writers in a global age. I B. Paulsrud, J. Rosén, B. Straszer \& A. Wedin (Red.), New perspectives on translanguaging and education (s. 56-71). Clevedon: Multilingual Matters.

See: http://www.multilingual-matters.com/display.asp?isb=9781783097807

2 Gabrielle smiler med de fine hvite tenner. og sier « jeg har allid drømt om den dagen» Gabrielle smiles with her nice white teeth. and says «I have always dreamt about this day»]

3 Fernando: «jeg elsker deg, ana bahebek, dostet darom, I love you, teiamo, Eg elsker deg og myliu tave» [«I love you, I love you, I love you, I love you, I love you, I love you and I love you»]

4 Gabrielle: \Ah, ah, Fernando»

5 Fernando: «jeg vil ikke forlate deg mer. La oss si til hele landsbyen, den 17. juni er bryllupet varrt» ["I don't want to leave you anymore. Let's tell the whole village, the 17th of June is our wedding»]

As we see in line 3 in extract 4, Fernando draws on the Norwegian, Arabic, Dari, English, Spanish and Lithuanian. Accordingly, the pupils combine their own home languages-Arabic, Dari and Lithuanian - with Norwegian, as well as with English and Spanish. The pupils' repertories and their linguistic choices reflect their own histories, not only pointing backwards to the past, but also forwards, anticipating future situations (cf. Busch, 2015: 17). For example, Spanish is a language Bahar has always wanted to learn. Spanish is also an official language in many Latin American countries, where the love story takes place. The other languages Fernando draws on, however, are traditionally not linked to this setting, and are thus found to belong to him personally and possibly to his transnational biography. In sum, the pupils use translanguaging as a strategically "rhetorical choice" (Canagarajah, 2011: 404) and for "literary effect" (García \& Li Wei, 2014: 27) to draw attention to Fernando's entire communicative repertoire, at the same time as it reminds us of the complexities of today's globalised world. Fernando can also be characterised as a multilingual and transnational person, having acquired several languages, while having lived in different places.

In contrast, Gabrielle's role may be interpreted as being traditional-it is the man who travels and the woman who stays behind and waits for him. However, it may also be interpreted in a more complex way. Her affirmative response in line 4 in extract 4 indicates that she understands Fernando's love message. It is not possible to know if Gabrielle has also travelled in her life, but it is not very likely that she has the exact same communicative repertoire as Fernando. It can therefore be assumed that she does not understand Fernando's declarations of love in all languages/language varieties. However, she does not stop to ask for clarification of the possible bits and pieces she does not understand. In fact, her affirmative response illustrates dispositions such as "a willingness to negotiate with diversity in social interactions [and] openness to difference" (Canagarajah, 2013: 5). Canagarajah stresses that these dispositions are not limited to multilinguals. Moreover, 'native/monolingual' speakers may also develop them as they encounter multilingual practices. As seen through their cast of characters, the pupils have not constructed the setting of their love story as unidirectional, stable, monolingual, monocultural. Moreover, its complexity is closely linked to the characters' outer and inner mobility.

To sum up so far, the pupils create a translanguaging space in their Norwegian school assignment in several ways (cf. Li Wei, 2011). Analytically, Bahar's reflections on her 
Dewilde, J. (2017). Multilingual young people as writers in a global age. I B. Paulsrud, J. Rosén, B. Straszer \& A. Wedin (Red.), New perspectives on translanguaging and education (s. 56-71). Clevedon: Multilingual Matters.

See: http://www.multilingual-matters.com/display.asp?isb=9781783097807

previous literacy experiences during an interview, as well as my study of her Facebook and informal interaction during school breaks with her friends, give me the opportunity to gain greater insight into the translanguaging space created in her school writing. The strategic inclusion of poetry as dialogue breaks with expected genre norms, and Fernando's multilingual line appears as a creative act which at the same time encourages us to think critical in terms of genre and people's linguistic and cultural identities in global times. In this way, the pupils challenge stable views of language, culture, place and genre.

I end this section by turning to the Norwegian language teacher's response to the pupils' text. In her feedback, the teacher explicitly acknowledges the pupils' rhetorical strategy, marking the line with multiple languages and commenting as follows:

\section{Extract 5.}

Så fint å bli elska på så mange språk! [How nice to be loved in so many languages!]

And of the poetry she writes:

\section{Extract 6.}

Så vakker bruk av diktene! Dette er jo virkelig romantisk. [Such beautiful use of poetry. This really is very romantic.]

In her general comments on the text, the teacher adds the following:

\section{Extract 7.}

Dere har mange vakre bilder i hodet, som dere formilder godt til teksten. Jeg liker at dere blander inn poesi og at dere bruker flere språk når Fernando sier at han elsker Gabrielle.

KREATIVT! [You have many beautiful pictures in your heads, which you convey well in your text. I like that you mix in poetry and that you use several languages when Fernando says that he loves Gabrielle. CREATIVE!]

In the assignment, the young people were asked to be creative. The teacher recognises their poetry and multilingual dialogue as creative acts. It is not possible to know if she also realises their critical potential in terms of challenging norms, expectations, beliefs and values, which are at the core of translanguaging spaces.

\section{"Reach for the stars to change the world"}

The second text was written by Bahar in connection with a mock exam for the subject English in April 2014. The pupils were given a preparation booklet containing, amongst other things, texts about and pictures of renowned people who have made a positive difference to the world, such as Mandela and Ghandi. The pupils were instructed to respond to the following task: 
Dewilde, J. (2017). Multilingual young people as writers in a global age. I B. Paulsrud, J. Rosén, B. Straszer \& A. Wedin (Red.), New perspectives on translanguaging and education (s. 56-71). Clevedon: Multilingual Matters.

See: http://www.multilingual-matters.com/display.asp?isb=9781783097807

How would you like to make a positive difference in the future-either in your working or private life? Write a text about how you-like many of the people mentioned in the Preparation Bookletcan make a positive difference for other people.

Bahar called her text "Reach for the stars to change the world." It is written in English, is 721 words long and consists of five paragraphs. The text is about a dream she has to dance in front of many people. She knows her parents will disapprove because, as a Muslim girl, she should not show her body's figure. She is determined to follow her dream at the same time as keeping her parents happy. The difference she will make will have an effect on Muslim girls, who should all have the right to follow their dreams.

Bahar's dream was not unfamiliar to me. Two months earlier she had posted a picture on Facebook with a young woman dancing in a puddle and the text "dance is freedom." Bahar accompanied the picture with the line "if someone could understand the deepest feeling/secret in your soul..." sticking to English, the language used in the picture and also a widespread language in social media. Her friend Nargis responded in Norwegian "hahahah that makes two of us," (Hahaha det er vi to om.) whereupon Bahar replied by drawing on Norwegian and Dari, respectively, "Yes definitely" (Ja bokhoda). The young people thus draw on three languages to make meaning. More so, not only do they share the same dream, they share a common biography since, like Bahar, Nargis was born in Afghanistan and now lives in Norway. Nargis' shift to Norwegian may be interpreted as a reminder of the importance of their move to Norway for this dream in the first place. Bahar's switch to Dari when addressing her friend is again "emblematic of certain [shared] cultural values and traditions" (cf. Creese \& Blackledge, 2015: 32). As discussed in related publications (Dewilde, in press; Dewilde \& Skrefsrud, 2016), Bahar perceives her Facebook profile as a "free space," away from the eyes of her family members. Bearing this in mind, the translanguaging space created here is one of great social and emotional importance (cf. Li Wei, 2011: 1224).

As I will show below, Bahar writes about this dream more extensively for her English mock exam, self-translating the gist of her Facebook post (cf. García \& Li Wei, 2014: 26-27). This time, her teacher is the imagined recipient—not her friends. Considering the fact that mock exams are a high-stakes activity in school where her English language proficiency will be evaluated, it is not surprising that Bahar sticks to Standard English as much as possible. Moreover, Canagarajah (2011: 404) argues that the "ability to assess the situation and frame one's language accordingly is part of a multilingual's rhetorical awareness and communicative proficiency." The content of Bahar's text, however, shows clear signs of drawing on different values and discourses.

Bahar starts her text in the following way: (The language of the excerpts has not been changed.)

\section{Extract 8.}

They say be unique and make a difference. That's what keeps me follow my dream. The one and only dream I have ever had. The dream that only I know and no one else. And this dream comes true the day when the whole world is watching me doing my dance steps. From children to grandparents, everyone is waiting for me to dance. Only me at the stage, lights on 
Dewilde, J. (2017). Multilingual young people as writers in a global age. I B. Paulsrud, J. Rosén, B. Straszer \& A. Wedin (Red.), New perspectives on translanguaging and education (s. 56-71). Clevedon: Multilingual Matters.

See: $\underline{\text { http://www.multilingual-matters.com/display.asp?isb=9781783097807 }}$

me, feeling the beats and the music and moving my body as I am free like a bird. To make a difference in dance history is my future. Just like Michael Jackson. He is death but his dance steps and name is still alive. And Shakira, the dance queen.

Bahar's dream is to make a difference in dance history, a dream which she may share with many girls in Norway. Michael Jackson and Shakira are also common references in youth culture, perhaps particularly in the Western world. In the second paragraph, however, the reader gets a sense of a possible conflict.

\section{Extract 9.}

Since I was a little girl, I loved to dance. And my family keeps often telling me that how much I was happy while dancing. I can remember how much people loved my dance, and they made me dance every time they saw me. I always enjoyed dancing, and I still do exactly the same.

Nothing has changed. And it will never change either. [...] And one day I will show the whole world, that how much I love dancing. And I will make my own dance history. When people read it, they say "wow" she was amazing.

As noted above, Bahar grew up in Afghanistan. When writing about her dream, an event she hopes will take place sometime in the future, she thinks back in time and place as she refers to "my family" and "people". The utterances "and I still do exactly the same. Nothing has changed. And it will never change either" makes the reader wonder why nothing has changed. We get a part of the answer in the next paragraph:

\section{Extract 10.}

I think everyone can make a difference in their life. It can be big or small, for good or for bad. Like Nelson Mandela, Mahatma Gandhi and many other important people like them. Everyone has that one secret that no one knows. And it can change their whole life. [...] No matter what it takes, I will take the risks too. Because if you want to get something, you must accept the risks too. I know I am going to have problems, because my parents are not agreeing with me. And they will not allow me easily. But I will never give up. I will keep their hearts and make my dream come true at the same time. $[\ldots]$

In this paragraph, Bahar reveals that dancing involves a risk because her parents do not agree. She is determined to keep them happy and pursue her dream. In the fourth paragraph, she elaborates on the oppositions she struggles with, putting them into a bigger context:

\section{Extract 11.}

The difference I want to make is also to have an effect on Muslim girls. Because a Muslim girl cannot show her body's figure. They cannot dance in public, or move their body while men are watching them. I am a Muslim girl self and I know many other girls who love to dance, but they are not allowed. They cannot even dance at small parties. And I want to change this situation. Because in my point of view they are taking Islam in in wrong way. I mean Islam is a religion of peace, and I don't think it is a big problem to show your dance talent. [...] And I want to give an 
Dewilde, J. (2017). Multilingual young people as writers in a global age. I B. Paulsrud, J. Rosén, B. Straszer \& A. Wedin (Red.), New perspectives on translanguaging and education (s. 56-71). Clevedon: Multilingual Matters.

See: $\underline{\text { http://www.multilingual-matters.com/display.asp?isb=9781783097807 }}$

example since I am talking about women's rights. And it is Malala, the Pakistani girl who stood up for the rights of girls. And this brave young lady made a difference in women's rights.

Bahar illustrates how she critically relates to different imagined communities, beliefs and attitudes. Even though there is a variety of traditional and more liberal views present in both Afghanistan and Norway, it is likely that Bahar's movement to Norway has strengthened her liberal attitudes to dance. By referring to Malala Mousafzai, who received the Nobel Peace Prize for her struggle against child oppression and children's rights to education, Bahar makes an explicit link to a member of an imagined Muslim community with more liberal views. She is determined to make a difference in her own life and in that of other Muslim girls creating something unique, something that the world had not imagined, which is being a Muslim girl dancing on a public stage. Writing about Muslim girls' rights in a mock exam in a Norwegian mainstream school, is a clear reminder that the world's oppositions occur in individual people's lives. Moreover, Bahar sets the issue on the agenda and thus makes it a global and not merely a local/national affair (cf. Warriner, 2007, 2012).

To sum up, Bahar is able to create a translanguaging space in her school assignment by drawing on her personal history, which is closely linked to her transnational biography, for comparison and innovation. Here, she sticks to Standard English most of the time, which is expected in an exam for the subject English. As we have seen from the Facebook extract, however, she communicates about this issue with her friend who has a similar transnational biography by drawing on English, Norwegian and Dari. Contentwise, she questions existing attitudes and beliefs about the possibility for Muslim girls to dance in the public sphere. Here, she shows her ability to go beyond boundaries when she creates new identities, values and practices in response to larger societal tensions. Moreover, analytically, the linking of Bahar's Facebook post to her mock exam makes it possible to gain a deeper insight into the translanguaging space she creates in the latter. In particular, the Facebook post makes us aware of the (emotional) momentum of the issue, not only in Bahar's life, but also in that of her friend. Also, the Facebook posting and ensuing exam text provide support for Canagarajah's (2013: 4) argument that language is only one semiotic resource among many.

In her feedback, the English language teacher acknowledges Bahar's rhetorical choices, as well as her positioning towards larger societal ideologies:

\section{Extract 12.}

Your text is the most personal and moving amongst all the texts I have read from the mock exams so far. You start off by telling how you would like to make a difference in your own life, which is all good and well. Yet, the full extent of your dreams and wishes becomes evident when you put the fulfilment of your own dreams and wishes into a larger context. I really look forward to watching you on stage someday! I will be there, I promise $: ;$

The teacher indirectly acknowledges the demanding situation Bahar encounters at times when relating to different imagined communities particularly in terms of values. Further, she praises Bahar for putting her own story into a wider context and thus drawing on her communicative 
Dewilde, J. (2017). Multilingual young people as writers in a global age. I B. Paulsrud, J. Rosén, B. Straszer \& A. Wedin (Red.), New perspectives on translanguaging and education (s. 56-71). Clevedon: Multilingual Matters.

See: http://www.multilingual-matters.com/display.asp?isb=9781783097807

repertoire in terms of cultural comparison. Similar assignments like this one, which stimulate Bahar to draw on her entire repertoire, including cultural comparison, would further develop her critical skills in terms of linking imagined communities.

\section{Final remarks}

This chapter set out to investigate the social space Bahar creates in her school writings by drawing on the full range of her communicative repertoire. It illustrates how her translanguaging and transnational literacy practices and translanguaging spaces in two school assignments are creative and critical acts. That is, Bahar can strategically follow or flout norms and conventions in terms of language and genre choice, while also critically challenging homogenous perceptions of language and culture.

The analytical possibilities the study of pupils' writings outside of school provides for understanding the social space their school writing creates have been stressed. That is, the trajectories between writings and literacy experiences in general from different times, places and repertoires provide deepened insight into the social space created by pupils in school writing. This is especially visible in the sense that Bahar makes an emotional investment in her writings by drawing on earlier (literacy) experiences, values and norms, and transforming them in a new setting. This investment is also underlined by the fact that she chose to share these particular two texts with me.

Finally, Blommaert (2010: 1) reminds us that the world has become tremendously complex, and "[t]hat [this] complexity needs to be examined and understood." Here, I have shown how studying transnational young people's texts may contribute to gaining a greater understanding of how globalisation is played out in their lives. Bahar very much appears to be an active agent in her social life with the capacity to change (our view of) society (cf. Li Wei, 2011: 1234), and is thus worth our attention. Also, if we are to persuade educators that the repertoires of students are going untapped, more research on how young people create translanguaging spaces is needed.

\section{References}

Adams, J. N. (2003) Bilingualism and the Latin Language. Cambridge: Cambridge University Press.

Baker, C. (2003) Biliteracy and transliteracy in Wales: Language planning and the Welsh national curriculum. In N.H. Hornberger (ed.) Continua of Biliteracy: An Acological Framework for Educational Policy, Research, and Practice in Multilingual Settings (pp. 71-90) Clevedon: Multilingual Matters.

Bhabha, H. (1994) The Location of Culture (2nd edn). Routledge: London.

Blommaert, J. (2010) The Sociolinguistics of Globalization. Cambridge: Cambridge University Press. 
Dewilde, J. (2017). Multilingual young people as writers in a global age. I B. Paulsrud, J. Rosén, B. Straszer \& A. Wedin (Red.), New perspectives on translanguaging and education (s. 56-71). Clevedon: Multilingual Matters.

See: http://www.multilingual-matters.com/display.asp?isb=9781783097807

Busch, B. (2015) Expanding the notion of the linguistic repertoire: On the concept of Spracherleben The lived experience of language Applied Linguistics 1-20.

Canagarajah, A. S. (2013) Introduction. In A.S. Canagarajah (ed.) Literacy as Translingual Practice: Between Communities and Classrooms (pp. 1-10). NY: Routledge.

Canagarajah, S. (2011) Codemeshing in academic writing: Identifying teachable strategies of translanguaging The Modern Language Journal 95 (iii), 401-417.

Copland, F. and Creese, A. (2015) Linguistic Ethnography. Collecting, Analysing and Presenting Data. Los Angeles: Sage.

Creese, A. and Blackledge, A. (2010) Translanguaging in the bilingual classroom: A pedagogy for learning and teaching? The Modern Language Journal 94 (i), 103-115.

Creese, A. and Blackledge, A. (2015) Translanguaging and identity in educational settings Annual Review of Applied Linguistics 35, 20-35.

Dewilde, J. (2013) Ambulating teachers: A case study of bilingual teachers and teacher collaboration. $\mathrm{PhD}$ thesis, University of Oslo.

Dewilde, J. (in press) 'Tell me how I can get to know you.' Negotiating research strategies with late arrivals in Norwegian schools in field conversations. SAGE Research Methods Cases 2016.

Dewilde, J. and Igland, M.-A. (2015) "No problem, janem". En transspråklig tilnærming til flerspråklige elevers skriving. In A. Golden and E. Selj (eds) Skriving på Norsk som Andrespråk. Vurdering, Opplaring og Elevenes Stemmer (pp. 109-126). Oslo: Cappelen Damm Akademisk.

Dewilde, J. and Skrefsrud, T.-A. (2016) Including alternatives stories in the mainstream. How transcultural young people in Norway perform creative cultural resistance in and outside of school. International Journal of Inclusive Education, 20 (10), 1032-1042.

Engen, T. O. (2010) Enhetsskolen og minoritetene [Comprehensive school and minorities]. In A. B. Lund and B. B. Moen (eds) Nasjonale Minoriteter i det Flerkulturelle Norge (pp. 121-139). Trondheim: Tapir akademisk.

Engen, T. O. (2014) The recognition of students' origin in liquid times. In H. Ragnarsdóttir and F. Dervin (eds) Origins: A sustainable Concept in Education (pp. 87-100). Rotterdam: Sense Publishers.

García, O. (2009) Bilingual Education in the 21st Century: A Global Perspective. Chichester: WileyBlackwell.

García, O. and Li W. (2014) Translanguaging: Language, Bilingualism and Education. Hampshire: Palgrave Macmillan.

Hornberger, N. H. (1990) Creating successful learning contexts for bilingual literacy. Teachers College Record 92, 212-229.

Hornberger, N. H. (2007) Biliteracy, transnationalism, multimodality, and identity: Trajectories across time and space Linguistics and Education 18, 325-334.

Hornberger, N. H. (ed.) (2003) Continua of Biliteracy: An Ecological Framework for Educational Policy, Research, and Practice in Multilingual Settings. Clevedon: Multilingual Matters.

Hornberger, N. H. and Link, H. (2012) Translanguaging and transnational literacies in multilingual classrooms: A biliteracy lens International Journal of Bilingual Education and Bilingualism 15 (3), 261-278.

Hvistendahl, R. (2009) Multilingualism in schools. Introduction and overview. In R. Hvistendahl (ed.) Flerspråklighet i Skolen (pp. 197-214). Oslo: Universitetsforlaget.

Li W. (2011) Moment Analysis and translanguaging space: Discursive construction of identities by multilingual Chinese youth in Britain Journal of Pragmatics 43 (5), 1222-1235. 
Dewilde, J. (2017). Multilingual young people as writers in a global age. I B. Paulsrud, J. Rosén, B. Straszer \& Å. Wedin (Red.), New perspectives on translanguaging and education (s. 56-71). Clevedon: Multilingual Matters.

See: http://www.multilingual-matters.com/display.asp?isb=9781783097807

MER (2007) Språk Bygger Broer [Language Builds Bridges]. Ministry for Education and Research. White Paper no. 23 2007-2008, accessed 02.08.2016.

http://www.regjeringen.no/pages/2077013/PDFS/STM200720080023000DDDPDFS.pdf.

MCC (2007) Mål og Meining: Ein Heilskapleg Norsk Språkpolitikk [Language and Meaning: A

General Norwegian Language Policy] Ministry of Culture and Church. White Paper no. 35 20072008, accessed 02.08.2016.

http://www.regjeringen.no/pages/2090873/PDFS/STM200720080035000DDDPDFS.pdf.

Ong, A. (1999) Flexible Citizenship: The Cultural Logics of Transnationality. Duham, NC: Duke University Press.

Vedøy, G. (2008) "En elev er en elev", "barn er barn" og "folk er folk": Ledelse i flerkulturelle skoler. [A pupil is a pupil", "children are children", "people are people": Leadership in multicultural schools]. PhD thesis, University of Oslo.

Warriner, D. (2007) Transnational literacies: Immigration, language learning, and identity Linguistics and Education (18).

Warriner, D. (2012) Multilingual literacies. In M. Martin-Jones, A. Blackledge and A. Creese (eds) The Routledge Handbook of Multilingualism (pp. 508-520). Oxon: Routledge. 